\title{
The relationship between the continental shelf regime and a new international instrument for protecting marine biodiversity in areas beyond national jurisdiction
}

\author{
Joanna Mossop ${ }^{1}$
}

\begin{abstract}
States have acknowledged that the new internationally legally binding instrument (ILBI) for the conservation and sustainable use of marine biodiversity beyond national jurisdiction must take account of the interests of coastal states in continental shelves that extend beyond 200 nautical miles. This article argues that the ILBI should go beyond repeating the existing legal position as set out in international treaties and customary international law. In particular, the concept of sedentary species is unhelpful in the context of a legal regime governing the use of marine genetic resources. The article makes a number of suggestions for possible inclusions in the ILBI to clarify the relationship between the continental shelf regime and the regime for biodiversity beyond national jurisdiction.
\end{abstract}

\section{Introduction}

The international community is in the process of discussing the elements of an international legally binding instrument (ILBI) for the conservation and sustainable use of marine biodiversity in areas beyond national jurisdiction (BBNJ). Among the

\footnotetext{
${ }^{1}$ Senior Lecturer, Victoria University of Wellington. Joanna.Mossop@ @uw.ac.nz. This is the author's final version of an article published in (2018) 75 ICES Journal of Marine Science 444-450 <https://doi.org/10.1093/icesjms/fsx111>.
} 
discussions, states have repeatedly commented on the need to respect the rights of coastal states with continental shelves that extend beyond 200 nautical miles. However, little detail about this has yet been discussed. The purpose of this paper is to analyse the respective rights and obligations of states operating in the vicinity of extended continental shelves and discuss how the ILBI could be used to clarify those obligations and create a workable legal framework. .

In June 2015, the United Nations General Assembly resolved to establish a preparatory committee that would make recommendations on the elements of a draft text of an ILBI to the General Assembly (GA Resn 69/292). This was the culmination of nine years of meetings by an ad-hoc working group established by the General Assembly to study issues relating to the conservation and sustainable use of BBNJ. The preparatory committee was instructed to consider the conservation and sustainable use of marine biological diversity of areas beyond national jurisdiction, including marine genetic resources, measures such as area-based management tools, environmental impact assessments and capacity building and the transfer of marine technology. At the time of writing, three meetings of the preparatory committee have been held.

Among the key debates that have emerged from this process is the issue of the legal regime that applies to marine genetic resources. The development of a marine biotechnology industry has led many states to believe that considerable profits can be derived from marine organisms. In particular, developing countries have argued that living organisms found in the seabed beyond national jurisdiction (the Area) are, or should be, covered by the common heritage of mankind principle in the United Nations Convention on the Law of the Sea (UNCLOS) (Leary, 2012; Treves, 2010). This would require the sharing of benefits derived from the exploitation of those organisms with the international community. Other states are opposed to applying common heritage to 
marine organisms beyond national jurisdiction. It is possible that negotiations may focus on creating a sui generis, or unique, regime that provides for access and benefit sharing processes, although which organisms will be subject to that regime is wide open at this stage.

Other issues arising from the discussions revolve around the protection of marine biodiversity. It has been noted that the high seas are regulated by sectoral regimes which are poorly coordinated. Some activities may not be regulated at all (Rochette et al., 2014; Gjerde et al., 2008). In light of this, there is a genuine concern that marine biodiversity is not being protected as well as it should be. Therefore, a range of proposals have centred around environmental protection mechanisms including area based management tools and requiring environmental impact assessments. One of the key issues is the relationship between obligations created by the ILBI and existing institutions.

During these discussions, it has often been pointed out that the area beyond national jurisdiction does not include the continental shelves of coastal states that extend beyond $200 \mathrm{~nm}$. In these cases, the coastal state has sovereign rights over the resources of the continental shelf, while the resources found in the water column are beyond national jurisdiction. As explained below, this legal separation of responsibility creates serious practical problems. It will be essential for the ILBI to address this problem.

Any consideration of protecting biodiversity in areas beyond national jurisdiction will need to address the fact that some activities will have effects across jurisdictional boundaries. This is particularly true in the case of the continental shelf beyond 200 nautical miles. Activities conducted in the high seas could have a direct or indirect impact on the biodiversity of continental shelves. For example, bottom trawling 
for high seas species will have a significant adverse impact on vulnerable benthic ecosystems in that location (Clark et al., 2016; Norse et al., 2012). The disposal of waste from vessels or land-based sources might impact on continental shelf species (RamirezLlodra et al., 2011). Carbon sequestration in the deep ocean that forms lakes of carbon dioxide above the seafloor could alter the acidity or oxygen level of the seawater, making it difficult for sedentary species to survive (Seibel and Walsh, 2001; Barry et al., 2004).

It is also important to remember that activities conducted by the coastal state on the continental shelf can have an impact on biodiversity in the water column. This may affect biodiversity within a state's jurisdiction (if it affects the exclusive economic zone (EEZ)), another state's jurisdiction (another EEZ) or the areas beyond national jurisdiction (the high seas). For example, oil and gas exploration and exploitation may impact on biodiversity through noise pollution from seismic surveys, accidental spills, the discharge of oily by-products of the production process, and the decommissioning of the rig (Harris et al., 2016). Deep-sea mining can result in habitat destruction and sediment plumes (Levin et al., 2016). Coastal states and states operating in the high seas will need to turn their minds to how to manage those effects.

This article sets out the key rights and obligations of coastal states in relation to the sedentary species of the continental shelf beyond 200 nautical miles and of flag states operating in the high seas above this shelf. It argues that the ILBI should go beyond restating the existing legal principles relating to the continental shelf beyond 200 nautical miles. Although existing international law relating to the protection of the environment goes some way to imposing obligations on coastal and flag states, arguably they have not received sufficient attention to date. In addition, some principles found in Part VI of UNCLOS, relating to the continental shelf, will not work effectively in 
the context of regulating access to marine genetic resources. The ILBI could contribute to clarifying the respective responsibilities of coastal states and states with vessels operating in the waters above the continental shelf. It may encourage cooperation that allows for effective management of activities that have an impact on the continental shelf resources. In doing so, it would further the overall goal of improving the protection and sustainable use of marine biodiversity. This article explores these issues in the context of the four areas identified by the General Assembly for consideration by the Preparatory Committee: marine genetic resources, area based management tools, environmental impact assessment and capacity building and technology transfer.

\section{Coastal state rights and obligations in respect of the continental shelf}

\section{beyond $200 \mathrm{~nm}$}

Article 77 of UNCLOS provides that the coastal state has sovereign rights over the continental shelf for the purpose of exploring it and exploiting its natural resources. These resources include both non-living resources such as oil and gas, and living resources that are sedentary species. Sedentary species are those organisms "which, at the harvestable stage, either are immobile on or under the seabed or are unable to move except in constant physical contact with the seabed or subsoil." The rights of the coastal state over the continental shelf do not affect the legal status of the waters above the shelf (UNCLOS, art. 78).

The focus of coastal state attention on sedentary species has tended to be on commercially valuable fisheries species such as oysters, clams, scallops, crabs and lobsters (Mossop, 2016). However, in the context of a conversation about protection and sustainable use of biodiversity, the jurisdiction of coastal states is equally relevant 
to other types of sedentary organisms, which may not have been traditionally viewed as commercially valuable. Traditional fishing has taken place beyond 200 nautical miles on some shelves, such as for scallops off the east coast of Canada and the United States, and for snow crabs in the Barents Sea. Because the parts of the continental shelf beyond 200 nautical miles will usually be very deep, it is less likely that commercial fishing of sedentary species will be the primary concern of most states. Instead, the focus is likely to be on the use of deep sea benthic ecosystems for biotechnology purposes (Leary et al., 2009). On extended continental shelves, species found at hydrothermal vents, cold seeps, or on seamounts may be of interest to researchers (Banks et al., 2015, Arrieta et al., 2010).

Coastal states must not take action that infringes or unjustifiably interferes with navigation and other rights and freedoms of other states (UNCLOS, art 78(2)). This compares with the regime for the EEZ, in which both coastal states and flag states must give due regard to the rights and duties of other states (UNCLOS, art 56(3) and 58(3)). Although coastal states must not interfere with the rights of states operating in the high seas, this does not mean that coastal state interests must automatically give way to the exercise of high seas rights and freedoms. Instead, a coastal state may only interfere with high seas rights to the extent strictly necessary for the coastal state to protect its interests in the continental shelf. (Mossop, 2016).

Coastal states have legal obligations to protect the biodiversity on their continental shelves. Part VI of UNCLOS imposes no obligation to protect sedentary species, compared to Part V relating to the EEZ, which imposes obligations on coastal states to ensure the sustainable utilisation of the living resources of the EEZ. However, Part XII of UNCLOS imposes a number of obligations on all states, including coastal 
states. In addition, other treaties and customary international law impose separate obligations.

First, coastal states must take steps to protect the environment under their jurisdiction, which includes the continental shelf beyond 200 nautical miles. Article 192 of UNCLOS imposes a general obligation on states to protect and preserve the marine environment. This has been interpreted as a positive obligation to take active measures to protect and preserve the marine environment, and a negative obligation not to degrade the marine environment (South China Sea Arbitration, para 941). Article 194 requires states to prevent, reduce and control pollution of the marine environment from any source. It also requires states to preserve and protect rare or fragile ecosystems as well as habitats. There can be no doubt that some continental shelf ecosystems will fall into this category.

The Convention on Biological Diversity (CBD) applies to areas under national jurisdiction and therefore applies to the extended continental shelf. Under the CBD, coastal states must develop national strategies for the conservation and sustainable use of biodiversity, identify and monitor components of biodiversity and where possible protect, manage and restore biodiversity and ecosystems (CBD, arts 6, 7, and 8).

Second, coastal states have responsibilities in respect of the environment beyond their jurisdiction. Article 194(2) of UNCLOS establishes that coastal states have a responsibility to ensure that activities under their jurisdiction or control are conducted so as not to cause damage by pollution to the environment of other states, and to ensure that pollution arising from their activities does not spread beyond the areas they exercise sovereign rights. It is noteworthy that this obligation appears to be stronger in the way it is phrased than many statements of a customary international law obligation to prevent transboundary harm. The obligation not to cause transboundary 
harm is often referred to as an obligation not to cause significant transboundary harm (Pulp Mills case, para 101).

The obligation to prevent transboundary harm applies to areas beyond national jurisdiction, which includes the high seas and the Area (UNCLOS, art 194(2)). According to the International Court of Justice (ICJ), states have a general obligation 'to ensure that activities within their jurisdiction and control respect the environment of other states or of areas beyond national jurisdiction' (Threats or Use of Nuclear Weapons, para 29). The application of the principle to areas beyond national jurisdiction was confirmed by the International Tribunal for the Law of the Sea (ITLOS) in its advisory opinion on the Responsibilities of States Sponsoring Activities in the Area (Responsibility of States, para 148). Therefore, coastal states with extended continental shelves must mitigate activities that have a negative impact on the marine environment of the high seas or the Area. Given that activities on the continental shelf beyond 200 nautical miles of necessity take place in the high seas, this is a particularly important obligation for coastal states to consider. The obligation to prevent harm is usually interpreted as an obligation to act with due diligence. This means that the coastal state must adopt appropriate rules and measures to ensure the outcome, but also monitor activities (Pulp Mills, para 194). The exercise of due diligence may require the application of the precautionary approach (Responsibility of States, para 135).

The coastal state is also under obligations to conduct prior assessment of activities on their extended continental shelf in some circumstances. This is found in article 206 of UNCLOS and is also a principle of customary international law (Pulp Mills, para 204; Certain Activities case, para 104; Responsibility of States, para 148). The obligation in article 206 applies in respect of any activities that may cause substantial pollution or significant and harmful changes to the marine environment, 
wherever it may occur. The customary international law obligation applies primarily where there is a significant risk of harm to transboundary areas or areas beyond national jurisdiction and has been held to be part of the obligation of due diligence.

Customary international law also provides obligations to cooperate and to notify and consult with other states when there is a risk of significant transboundary harm (Certain Activities case, para 106).

Therefore, coastal states have both rights and obligations in relation to the continental shelf beyond 200 nautical miles. The fact that a coastal state has the exclusive right to explore, exploit and conserve the resources of the extended continental shelf should be recognised. Because the protection of biodiversity in the vicinity of the shelf will depend on coastal states observing their environmental obligations, it would make sense for the ILBI to reflect and incorporate those principles. The sections below expand on how that recognition might be put into effect.

\section{The rights and obligations of flag states in relation to the continental shelf beyond 200 nautical miles}

Although the rights of the coastal state to the continental shelf do not affect the status of the high seas above (UNCLOS, art 78(1)), in reality the uses of the continental shelf and the high seas may come into conflict. The exercise of high seas freedoms can impact on the rights of the coastal state in respect of the resources of the continental shelf. An obvious example of this is the use of bottom fishing that targets non-sedentary species but has a significant impact on ecosystems that include sedentary species. As noted above, flag states owe no express obligation to give 'due regard' to coastal state 
interests in the continental shelf. However, the history of the Continental Shelf Convention 1958, on which Part VI of UNCLOS is based, is clear that high seas rights will sometimes need to be curtailed to protect coastal state interests (Mossop, 2016).

There is no doubt that the flag state must ensure its vessels comply with the laws of the coastal state in relation to the resources under the coastal state's control. The sovereign rights of a coastal state in the EEZ 'encompasses all rights necessary for and connected with the exploration, exploitation, conservation and management of the natural resources, including the right to take the necessary management measures' $(M / V$ Virginia $G$, para 211). In the $M / V$ Virginia $G$ case, ITLOS found that the coastal state could regulate bunkering of fishing vessels so long as it was connected to fishing (para 215). In addition, a flag state has an obligation arising from article 192 to ensure compliance by its vessels flying its flag with the conservation measures concerning living resources in the EEZ (Fisheries Advisory Opinion, para 120).

Although article 77 does not refer explicitly to 'conservation and management' of continental shelf resources (Mossop, 2007), it would seem a logical step to say that the flag state also has an obligation to comply with coastal state conservation measures enacted in respect of sedentary species. UNCLOS does not enter into similar detail regarding the continental shelf compared to the EEZ. Nevertheless, the nature of sovereign rights in both areas is similar. As detailed above, coastal states do bear responsibility for the protection of biodiversity on their continental shelf. Therefore, coastal states will, in some circumstances, be able to restrict the activities of other states, such as bottom trawling, if it is reasonably connected with the exploration and exploitation of sedentary species. (Mossop, 2016).

The flag state also has a number of environmental obligations that qualify its high seas freedoms. These include the obligations in Part XII of UNCLOS, and it is 
clear that those articles apply to vessels operating on the high seas (South China Sea, para 940). The Arbitral Tribunal in the South China Sea case found a failure to prevent the large scale harvesting of corals and giant clams could amount to a breach of articles 192 and 194(5) (South China Sea, para 960). These obligations reinforce the view that coastal state regulations imposed to protect sedentary species as part of an ecosystem should be respected by flag states, unless they infringe or unjustifiably interfere with high seas freedoms.

\section{The tension between concepts of biodiversity and sedentary species}

It should be noted that the concept of sedentary species as contained in Part VI of UNCLOS can be inconsistent with the focus on the protection of biodiversity in Part XII of UNCLOS, in the CBD, or in the potential ILBI to protect BBNJ. The key problem is that the concept of biodiversity is dramatically different from UNCLOS's allocation of rights over resources. The Convention on Biological Diversity (CBD) defines biodiversity as "the variability among living organisms from all sources including, inter alia, terrestrial, marine and other aquatic ecosystems and the ecological complexes of which they are part; this includes diversity within species, between species and of ecosystems" (Art 2, CBD). As such, the idea of biodiversity is intimately associated with ecosystems rather than individual species. One of the strengths of the concept of biodiversity was the move away from a single species model of environmental management to reflect the importance of the interdependence of organisms and ecosystems (Franklin, 1993).

In contrast, the definition of sedentary species as a "resource" over which coastal states have control dates back to the 1950s and reflects an anthropocentric 
approach to the environment as a resource to be exploited (Scott, 1992). It views commercially valuable species in isolation from the ecosystem in which they are found, and Part VI of UNCLOS makes no reference to sustainability or environmental protection. This approach was carried over into UNCLOS from the Convention on the Continental Shelf without modification. The definition of sedentary species leads to some particular problems when applied in a modern context to BBNJ.

First, UNCLOS is clear that the coastal state has exclusive rights over some organisms found on the continental shelf, but not others. The determination of exactly which commercially valuable species were included within the definition of sedentary species has proven controversial in the past, primarily because the definition 'has little or no relationship to biological taxonomy' (Allen, 2001). For example, crabs, lobsters and scallops are all capable of independent movement off the seafloor and states have disagreed about whether they are correctly classified as sedentary species (Mossop, 2016). The definition is difficult to apply even in situations where considerable amount is known about the biology of the species concerned (Allen, 2001). If the focus is on a particular ecosystem, such as a hydrothermal vent or a seamount, discerning between organisms that are sedentary versus those that are not will be an order of magnitude more complex.

Second, the idea that sedentary and non-sedentary organisms are subject to different legal regimes does not make sense when considering species located in the same ecosystem (Korn et al., 2003). A coastal state would have legal rights and obligations in respect of some organisms but not others. For example, at a hydrothermal vent, coastal states would have sovereign rights in relation to tube worms but not the shrimps that live in the same ecosystem. And yet, this is the consequence if the 
UNCLOS sedentary species regime is applied to ecosystems located on a continental shelf beyond $200 \mathrm{~nm}$.

\section{Recommendations for the ILBI}

The General Assembly identified four elements that needed to be addressed in the preparatory committee for the ILBI. These were marine genetic resources, area based management tools, environmental impact assessment and capacity building and technology transfer. The following sections consider how the ILBI could develop the legal principles relating to the intersection between the continental shelf and the BBNJ regimes.

\section{Marine genetic resources}

In the context of bioprospecting, the sedentary species definition is unhelpful for a number of reasons. One problem is that the genetic material of an organism can be sampled when a species is an adult or when the organism is in a larval form. For many sedentary species, their larvae is distributed in the water column as juveniles. The larvae contain the same genetic material as an adult. This raises questions about whether the larvae, if collected by researchers in the water column, are covered by the sovereign rights of the coastal state. The Convention refers to species that are sedentary 'at the harvestable stage' which is not easily applied to a biotechnology context (Allen, 2001; Mossop, 2016, Mossop 2017).

Another example of the problems posed by the definition is that scientific researchers can now gather genetic material from environmental DNA rather than 
requiring a sample of the organism itself. This genetic material may comprise skin, faeces, mucus and other matter that is in the water (Barnes and Turner, 2016). Some of the genetic material could be used for biotechnology purposes (Chistoserdova, 2010). It is possible for a researcher to gather DNA from a sedentary species without collecting the actual organism or even making contact with the sebed.

Given the many difficulties with applying the sedentary species definition in relation to marine genetic resources, if the ILBI simply repeats the position that coastal states have sovereign rights over sedentary species, this will not resolve these problems. Instead, the agreement should clarify how the coastal state rights works in a genetic material context. One possibility that is being discussed is that the ILBI should create a sui generis regime for marine genetic resources for the high seas and the Area (Mossop, 2017). If so, this should include a mechanism that balances the rights of coastal states and flag states in an equitable manner. The challenge will be how to recognise the rights of coastal states in a way that reflects the level of their interest. One could imagine a variety of ways in which this might be done. First, the ILBI could take a restrictive interpretation of coastal state rights. Second, the ILBI could expand coastal state rights to cover seabed ecosystems. Finally, coastal states could relinquish rights over the genetic resources of sedentary species in return for some advantages under a global access and benefit sharing regime.

One option is to stipulate that the coastal state will only have sovereign rights over species that are sampled directly from the continental shelf. If such samples are of sedentary species, the coastal state has the right to control access to such species, and to enter into access and benefit sharing arrangements in relation to the use of those species. However, if juveniles are collected in the water, or if environmental DNA is collected near, but not on, the continental shelf, this would fall outside the coastal state's 
jurisdiction. The advantage of this is that it avoids the question of when the "harvestable stage' of the organism is. It also simplifies the issue for both states and researchers, who will know what legal regime applies based on the location of the organism or DNA that is sampled. Where the coastal state has concerns about the protection of fragile ecosystems, it may be able to impose conditions on access. The key disadvantage is that this perpetuates a divided ecosystem approach, whereby some species in the same ecosystem are under the control and jurisdiction of the coastal state, while others are subject to the high seas regime. It is also unlikely that the coastal state could prohibit access to the non-sedentary species in the ecosystem even if it is concerned that the research activity might be harmful to the environment in some way. For example, could a coastal state impose a marine protected area to protect sedentary species in a vulnerable marine ecosystem and insist that researchers refrain from accessing the nonsedentary species on the basis that sedentary species will be affected? This would seem doubtful in the current legal framework under UNCLOS unless there was a clear and significant detriment to the coastal state interests in the sedentary species.

A second approach would be to create a 'continental shelf benthic zone' within which the coastal state would have rights to exploit the genetic resources of the shelf, but also responsibilities to protect vulnerable marine ecosystems. This would extend the rights of the coastal state to all organisms in seabed ecosystems. This is consistent with the view of some commentators who have suggested that organisms found at hydrothermal vents should be legally managed as an ecosystem (Korn et al., 2003; Leary, 2007; Oude Elferink, 2007). The justification for such an approach would be that it better reflects an ecosystem approach to management of biodiversity on the continental shelf. It also would be simpler to apply than the sedentary/non-sedentary approach mentioned above. If the coastal state was not entitled to claim rights to genetic 
material found outside the benthic zone, this would balance the interests of the coastal state and researchers as some genetic material from the benthic zone will inevitably be found elsewhere as juveniles or environmental DNA. Considerable thought would need to be given to the definition of the continental shelf benthic zone: is it based on a uniform distance from the shelf, or would it be defined more in relation to particular types of ecosystems (Leary, 2007)?

A third option would be to incorporate sedentary species on the continental shelf in a sui generis regime that would apply to genetic resources in the high seas and in the Area. This would require coastal states to give up the exclusive right to genetic material in sedentary species, but in return coastal states with extended continental shelves could be given special status when applying any benefit sharing provisions under the sui generis regime. The details of such an arrangement would depend on the details of any such regime. The advantage would be that the problematic application of the sedentary species concept to genetic material would be completely avoided. The challenge would be to design a regime that adequately 'compensated' coastal states for the perceived losses associated with the removal of their interest. However, the difficulties already discussed mean that coastal states should not overestimate the value of their sovereign rights to the genetic resources of sedentary species beyond 200 nautical miles.

All of these options would involve some compromise by all states, as they would involve, to a greater or lesser extent, a departure from a strict application of the sedentary species concept. There will undoubtedly be political barriers to be overcome. However, it is preferable to have a workable system rather than attempt to perpetuate the sedentary species definition in a context that it was never intended to cover. 


\section{Area Based Management Tools (ABMT)}

Although it is not yet clear what shape the ABMTs will take under an ILBI, it cannot be denied that the coastal State will have an important interest in any ABMTs established in the high seas above its extended continental shelf. At a minimum, coastal states should be consulted when ABMTs are proposed for an area in the vicinity of their extended continental shelf. More substantive requirements could expand on obligations to cooperate with the coastal state.

A primary interest of the coastal State will be to ensure that any measures implemented under an ABMT would not interfere with its rights over sedentary species, or in its exploration and exploitation of the continental shelf. For example, restrictions on noise in the water column could impact on the ability of the coastal state to authorise seismic surveys for hydrocarbons in the continental shelf. In such a case, the coastal state interests should be considered in the creation of the mechanisms which can be drafted so as to not interfere with coastal state rights. Coastal states might wish to see an opt-out provision if they believe that the ABMT would restrict their interests. A general principle that the parties should not undermine coastal state rights might be worth including. The process should contain a dispute settlement process to resolve disagreements about the appropriate levels of environmental protection.

Another factor to consider is the coastal state may wish to establish ABMTs for the water above the extended continental shelf in order to support environmental protection measures taken in respect of shelf biodiversity. At present, few mechanisms exist to facilitate coherent measures at the request of the coastal state. One situation where coastal states have taken steps to protect benthic ecosystems from high seas activities is in the Oslo/Paris Convention (OSPAR) region in the north-east Atlantic. 
Portugal and the United Kingdom have worked with OSPAR and the North East Atlantic Fisheries Commission (NEAFC) to put in place measures above their continental shelves beyond 200 nautical miles. For example, NEAFC has closed some areas above the continental shelf of the UK and Portugal to bottom fishing in order to protect seamount ecosystems (Hall-Spencer, 2009; Ribeiro, 2014; Mossop, 2016). However, not all regions have existing organisations to consider coastal state requests for protection, or have organisations with the capacity to do so. In the absence of a regional organisation and regional fisheries management organisation such as OSPAR and NEAFC, attempts to get protection in the high seas will rely on working through a range of existing sectoral organisations (Druel et al., 2012; Freestone, 2014).

In order to facilitate the consideration of protection mechanisms relating to the extended continental shelf, the ILBI should include a process that allows a coastal state to initiate a discussion about using ABMTs to support coastal state objectives. The final shape of this process could vary depending on the final content of the ILBI and how it provides for the establishment of ABMTs. Of course, one of the key issues that needs to be resolved in the negotiations is the relationship between the ILBI and other regional and global organisations. If the ILBI ultimately leaves the establishment of ABMTs to such organisations, it could still set out some general principles relating to the relationship between ABMTs and coastal states. It would however, require coastal states to work with existing organisations to achieve their goals.

\section{Environmental Impact Assessments}

As discussed above, the obligation to conduct environmental impact assessments in certain cases is already a matter of international treaty and customary law. Both coastal 
states and flag states must ensure that assessments are conducted where there is a risk of significant transboundary harm or harm to the areas beyond national jurisdiction. For the coastal state, this will require careful consideration for almost all activities on the continental shelf beyond 200 nautical miles. The obligation to conduct assessments is closely connected to obligations to notify and consult with affected states. Arguably then, it is already part of customary international law that the coastal state be notified and consulted if activities in the high seas threaten the biodiversity of the continental shelf. At a minimum, the ILBI can articulate these obligations clearly.

An obligation to notify and consult does not provide the coastal state with a right to veto activities undertaken by other states in the high seas. A more complicated question is whether the ILBI could clarify matters that require the permission of the coastal state before they can take place. For example, it might be possible to argue that some activities (such as bottom fishing) are so likely to interfere with coastal state interests that permission is required before it is conducted on the continental shelf by other states (Mossop, 2016).

Another matter which the ILBI could assist with is the notification requirement on coastal states when they conclude that activities under their jurisdiction may have negative consequences on the high seas. Under existing international law, it is clear that there is an obligation to notify and consult with neighbouring states if there is a risk of significant transboundary harm. But, if the risk of harm is to the high seas, how is the coastal state's obligation to notify to be satisfied? The ILBI could create a reporting system which facilitates the notification of potential risks identified by environmental impact assessment.

\section{Capacity Building and Technology Transfer}


A considerable problem for coastal states is the lack of available information about the biodiversity on their continental shelf beyond 200 nautical miles. This problem is particularly acute for developing countries. It is expensive to study the deep sea, and the majority of scientific expeditions are conducted by researchers from developed countries. It also seems that, in order for a strong case to be made at the international level for protection of biodiversity on the continental shelf or in areas beyond national jurisdiction, this will have to be based on good science (O'Leary et al., 2012; Freestone, 2014). In the absence of scientific evidence of the existence of vulnerable marine ecosystems, for example, it may be difficult to convince the international community to suspend fishing in an area.

With this in mind, any assistance that can be provided to coastal states to increase their understanding of the biodiversity on their continental shelf will assist with the broader goal of preserving and protecting marine biodiversity. Although it is difficult to incorporate this into treaty language, one of the objectives of the capacity building effort should be focused on improving the ability of coastal states to protect their biodiversity. This could be done through creating scientific partnerships with developing country researchers.

\section{Conclusion}

The foregoing discussion has highlighted some of the issues relating to the intersection between the continental shelf beyond 200 nautical miles and the protection of biodiversity beyond national jurisdiction. The primary difficulty is the fact that the concept of sedentary species, which underpins the coastal states' interest in the biodiversity of the shelf, was designed for a very different purpose than the protection

of biodiversity. It is almost impossible to apply in the context of genetic resources when 
there is a different legal regime that applies to the non-sedentary species in the water above the shelf.

Of course, it is still early in the negotiations and it is impossible to predict how much content the international community will choose to include in the ILBI, and how much will be left to existing organisations. However, the ILBI can, and should, go beyond simply repeating the content of UNCLOS in relation to the continental shelf. Instead, there is an opportunity to create a more workable system and avoid unnecessary conflicts by elucidating expectations on both coastal and flag states operating on and in the vicinity of the continental shelf. At the very least, the ILBI should set out clearly the environmental obligations that apply to such activities including obligations to assess the environmental impacts of the activities, and to notify and consult with affected states before undertaking activities that have a possibility of harm to the marine environment. It would be desirable to articulate an obligation to cooperate with the coastal state when other states are undertaking activities that could intersect with the coastal state's rights. In relation to marine genetic resources and ABMTs, the ILBI could go further and impose new arrangements that protect the interests of coastal states and flag states, while pursuing the goal of the protection of marine biodiversity on and beyond the extended continental shelf. Finally, this article has suggested some options for moving beyond the problems that arise when applying the definition of sedentary species to marine genetic resources.

\section{References}

\section{Treaties}


Convention on Biological Diversity (opened for signature 5 June 1992, entered into force 29 December 1993) 760 UNTS 79.

Convention on the Continental Shelf (opened for signature 29 April 1958, entered into force 10 June 1964) 499 UNTS 312.

United Nations Convention on the Law of the Sea (opened for signature 10 December 1982, entered into force 16 November 1994) 1834 UNTS 397.

\section{Cases}

Certain Activities Carried out by Nicaragua in the Border Area/Construction of a Road in Costa Rica Along the San Juan River (Costa Rica v Nicaragua) (Judgment) ICJ, 16 December 2015.

Legality of the Threat or Use of Nuclear Weapons (Advisory Opinion) [1996] ICJ Reports 266.

M/V Virginia G (Panama/Guinea-Bissau) (Judgment) [2014] ITLOS Reports 4.

Pulp Mills on the River Uruguay (Argentina v Uruguay) (Judgment) [2010] ICJ Reports 14.

Request for an Advisory Opinion Submitted by the Sub-Regional Fisheries Commission (SRFC), (Advisory Opinion) ITLOS Reports, 2 April 2015.

Responsibilities and Obligations of States Sponsoring Persons and Entities with Respect to Activities in the Area (Advisory Opinion) (2011) 50 ILM 458.

South China Sea (Philippines v China) (Award) PCA Case No 2013-19, 12 July 2016 


\section{Secondary Sources}

Allen, C.H., 2001. Protecting the Oceanic Gardens of Eden: International Law Issues in Deep-sea Vent Resource Conservation and Management. Georgetown International Environmental Law Review, 13: 563-660.

Arrieta, J.M., Arnaud-Haond, S. and Duarte C.M., 2010. What lies underneath: Conserving the ocean's genetic resources. Proceedings of the National Academy of Sciences, 107: 18318-24.

Banks, M., Bissada, C., Eghtesadi Araghi, P., Escobar-Briones, E., Gaill, F., Juniper, S.K., Kawser, A., Kenchington, E., Preston, N., Procaccini, G., Ramaiah, N., Rice, J., Rogers, A., Rommens, W., Senlin, Z. and Thorndyke, M., 2015. Use of Genetic Resources. First Global Integrated Marine Assessment. www.worldoceanassessment.org.

Barnes, M.A. and Turner, C.R., 2016. The Ecology of Environmental DNA and Implications for Conservation Genetics. Conservation Genetics, 17: $1-17$.

Barry, J.P., Buck, K.R., Lovera, C.F., Kuhnz, L., Whaling, P.J., Peltzer, E.T., Walz, P. and Brewer, P.G., 2004. Effects of direct ocean CO2 injection on deep-sea meiofauna. Journal of Oceanography, 60(4): 759-766.

Chistoserdova, L., 2010. Recent Progress and New Challenges in Metagenomics for Biotechnology. Biotechnology Letters, 32: 1351-1359.

Clark, M. R., Althaus, F., Schlacher, T., Williams, A., Bowden, D. A., and Rowden, A. A. 2016. The Impacts of Deep-sea Fisheries on Benthic Communities: A Review. ICES Journal of Marine Science, 73.suppl 1: i51-i69.

Druel, E. and Gjerde, K.M., 2014. Sustaining marine life beyond boundaries: Options for an implementing agreement for marine biodiversity beyond 
national jurisdiction under the United Nations Convention on the Law of the Sea. Marine Policy, 49: 90-97.

Druel, E., Ricard, P., Rochette, J. and Martinez, C., 2012. Governance of marine biodiversity in areas beyond national jurisdiction at the regional level: filling the gaps and strengthening the framework for action. Studies, 4: 12-21.

Franklin, F. 1993. Preserving biodiversity: Species, ecosystems or landscapes?. Ecological Applications, 3(2): pp. 202-205.

Freestone, D., 2014. Can Existing Institutions Protect Biodiversity in Areas Beyond National Jurisdiction? Experiences from Two Ongoing Processes. Marine Policy, 49: 167-175.

Gjerde, K.M., Dotinga, H., Hart, S., Molenaar, E.J., Rayfuse, R. and Warner, R., 2008. Regulatory and governance gaps in the international regime for the conservation and sustainable use of marine biodiversity in areas beyond national jurisdiction. IUCN, Gland, Switzerland.

Hall-Spencer, J.M., Tasker, M., Soffker, M., Christiansen, S., Rogers, S., Campbell, M. and Hoydal, K., 2009. Design of Marine Protected Areas on high seas and territorial waters of Rockall Bank. Marine Ecology Progress Series, 397: 305-308.

Harris, P., Alo, B., Bera, A., Bradshaw, M., Coakley, B., Einar Grosvik, B., Lourenço, N., Renya Moreno, J., Shrimpton, M., Simcock, A., and Singh, A. 2016. Offshore hydrocarbon industries. In The First Global Integrated Marine Assessment, United Nations, New York.

Korn, H., Friedrich, S. and Feit, U., 2003. Deep Sea Genetic Resources in the Context of the Convention on Biological Diversity and the United Nations Convention on the Law of the Sea. Bundesamt für Naturschutz, Bonn. 
Leary, D. 2012. Moving the marine genetic resources debate forward: some reflections. The International Journal of Marine and Coastal Law. 27(2): $435-448$.

Leary, D., Vierros, M., Hamon, G., Arico, S. and Monagle, C., 2009. Marine genetic resources: a review of scientific and commercial interest. Marine Policy, 33(2): 183-194

Leary, D. 2007. International Law and the Genetic Resources of the Deep Sea, Martinus Nijhoff, Leiden.

Levin, L.A., Mengerink, K., Gjerde, K.M., Rowden, A.A., Van Dover, C.L., Clark, M.R., Ramirez-Llodra, E., Currie, B., Smith, C.R., Sato, K.N. and Gallo, N. 2016. Defining 'serious harm' to the marine environment in the context of deep-seabed mining. Marine Policy, 74: 245-259.

Mossop, J. 2017. Marine Genetic Resources and the Need for an Integrated Approach to the Seabed and Water Column. In Biodiversity beyond National Jurisdiction: A Navigating Guide through the New Implementing Agreement to UNCLOS. Ed. by André de Paiva Toledo and Virginie JM Tassin. D'Placido Editora, forthcoming.

Mossop, J. 2016. The Continental Shelf Beyond 200 Nautical Miles: Rights and Responsibilities. Oxford University Press, Oxford.

Mossop, J., 2007. Protecting Marine Biodiversity on the Continental Shelf beyond 200 nautical miles. Ocean Development \& International Law, 38(3): 283 304.

Norse, E.A., Brooke, S., Cheung, W.W., Clark, M.R., Ekeland, I., Froese, R., Gjerde, K.M., Haedrich, R.L., Heppell, S.S., Morato, T. and Morgan, L.E., 2012. Sustainability of deep-sea fisheries. Marine Policy, 36(2): 307-320. 
O'Leary, B.C., Brown, R.L., Johnson, D.E., Von Nordheim, H., Ardron, J., Packeiser, T. and Roberts, C.M., 2012. The first network of marine protected areas (MPAs) in the high seas: the process, the challenges and where next. Marine Policy, 36(3): 598-605.

Oude Elferink, A.G., 2007. The Regime of the Area: Delineating the Scope of Application of the Common Heritage Principle and the Freedom of the High Seas. International Journal of Marine and Coastal Law, 22(1): 143-176.

Ramirez-Llodra, E., Tyler, P.A., Baker, M.C., Bergstad, O.A., Clark, M.R., Escobar, E., Levin, L.A., Menot, L., Rowden, A.A., Smith, C.R. and Van Dover, C.L. 2011. Man and the last great wilderness: human impact on the deep sea. PLoS One, 6(8): e22588.

Ribeiro, M.C., 2014. Marine Protected Areas: The Case of the Extended Continental Shelf. In 30 Years After the Signature of the United Nations Convention on the Law of the Sea: The Protection of the Environment and the Future of the Law of the Sea. Ed. by M.C. Ribeiro. Coimbra Editora, Coimbra.

Rochette, J., Unger, S., Herr, D., Johnson, D., Nakamura, T., Packeiser, T., Proelss, A., Visbeck, M., Wright, A. and Cebrian, D., 2014. The regional approach to the conservation and sustainable use of marine biodiversity in areas beyond national jurisdiction. Marine Policy, 49:109-117.

Scott, S.V., 1992. The Inclusion of Sedentary Fisheries Within the Continental Shelf Doctrine. International and Comparative Law Quarterly, 41: 788-807. Seibel, B.A. and Walsh, P.J., 2001. Potential impacts of CO2 injection on deep-sea biota. Science, 294 (5541): 319-320. 
Treves, T.,. 2010. Principles and objectives of the legal regime governing areas beyond national jurisdiction. In The International Legal Regime of Areas Beyond National Jurisdiction: Current and Future Developments, pp. 5-26. Ed. by E.J. Molenaar and A.G. Oude Elferink. Brill, Leiden. 